\title{
Prediction for driving behaviour in connection with socio - demographic characteristics and individual value system
}

\author{
K.J. Lazdins and K. Martinsone \\ Rīga Stradiṇš University, Riga, Latvia
}

\begin{abstract}
The aim of research "prediction for driving behaviour in connection with socio-demographic characteristics and individual value system" was to examine characteristics of individual value system prediction for driving behavior. It raised fundamental question for the research: 1. which of the individual value system characteristics predict driving behavior controlling gender and age.

In the study 108 respondents participated, $40(37.0 \%)$ men and $68(63.0 \%)$ women who filled the questionnaire on the Internet. Two questionnaires were used - "Latvian driving behavior survey" [1], the value and levels of availability relations in different spheres of life" [2, 3].

The results showed that the value system integrity/disintegrity indicator predicts distracted driving, explains $18 \%$ of variation and is statistically significantly. Internal vacuum and age statistically significantly negatively predicts risky driving explaining $17 \%$ of variation. Age statistically significantly predicts safe and courteous driving, explains $12 \%$ of variation. Value system integrity/disintegrity indicator and gender, statistically significantly negatively predicts summary indicator of dangerous driving explain $22 \%$ of variation. Age statistically significantly negatively predicts distracted driving, explains $30 \%$ of variation.

The results can serve as the basis to create new driving behavior interventions and also applicable to psychologist's professional work, when counseling individuals of this group, as well as can be used in the future development of the field, science and research.
\end{abstract}

Key words: aggressive driving, distracted driving, driving behavior, individual values, risky driving, safe driving.

\section{Introduction}

Several countries have made fatal road accident reduction, but the total number of accidents remains unacceptably high -1.25 million people a year [4]. Although in recent years the number of fatal collision in Latvia has decreased, but in comparison with other European Union countries, it is still quite high. In 2012 there was a significant reduction in road traffic accidents, but unfortunately, in 2013 and 2014, road traffic accidents occur on an upward trend [5].

The number of factors causing road traffic accidents can be divided into: vehicle factors, environmental factors, as well as human factors [6]. Previous research has shown that about 
$40 \%$ of road traffic accidents are directly caused by the human factor and indirectly involved for about $50 \%$ of accidents, so then totally approximately $90 \%$ of road traffic accidents are directly or indirectly related to the human factor. Environmental factors (roadways conditions, weather conditions) is the possible cause of about $34 \%$ of accidents and vehicle factors as causes of accidents provides only for $13 \%$ of accidents [7]. By the concept of the human factor are understood human psychological conditions, cognitive processes, personality factors, demographic factors, attitudes [8].

Values are defined as long term belief that a particular form of action or destination of existence is personally, socially preferable and more desirable compared to other form of action or destination of existence [9].

In the doctoral thesis of Latvian researcher Inese Muzikante is shown that individual values can significantly predict risky driving, the value "dominion" is the most important predictor of violation from all values, value "conformism" can be an important predictor of risky driving, value "stimulation" (sensation seeking) does not predict risky driving, value for "safety" in only one part of the study predicts risky driving, which means that it is not stable predictor for risky driving [10].

Currently there is no clear evidence that the individual value system characteristics predict driving behavior, the authors not been able to find such studies, so it is necessary to examine whether an individual value system characteristics predict driving behavior and if so, then how.

The aim of the research was to examine characteristics of individual value system prediction for driving behaviour.

Research question was: which of the individual value system characteristics (internal vacuum, internal conflict, the neutral zone, value system integrity/disintegrity indicator) predict driving behaviour (distracted driving, aggressive behaviour towards other traffic participants, risky driving, safe and courteous driving) controlling by gender and age.

\section{Materials and methods}

\subsection{Participants}

The research involved 108 Latvian respondents participated. There were 40 (37.0\%) men and $68(63.0 \%)$ women, aged from 19 to 58 years. Based on descriptive statistics, the empirical distribution does not match the normal distribution, which means that the results are attributable to the sample not to the population of Latvia.

\subsection{Instruments}

2 questionnaires were used in this research:

1) Questionnaire on Latvian driving behaviour [1]. Respondents were asked to answer how often they act while driving like described in the proposed statements, using 5 point Likert scale $(1-$ never, 5 - very often). The final version of the survey consists of 26 statements that allow to evaluate four driving behaviour types: (1) risky driving (6 statements), (2) aggressive behaviour towards other traffic participants (6 statements), (3) distracted driving (6 statements), (4) safe and courteous driving (6 statements).

2) "The value and levels of availability relations in different spheres of life" (Уровень соотношения «ценности» и «доступности» в различных жизненных сферах) [2, 3]. Respondents were proposed to fill out two tables - at first they needed to create hierarchy from 12 different values, second - they needed to decide which of them is easier to reach from their point of view. The values were: (1) active life, (2) health, (3) interesting job, (4) 
beauty of nature and art, also enjoying it, (5) love, (6) material ensured life, (7) reliable and good friends, (8) self confidence, (9) exploration, the opportunity to expand their horizons, education, (10) freedom as the independence of the actions and activities, (11) happy family life, (12) innovation [2]. The method is based on the idea of the two spheres of conscious activity, which by its nature is analogous to these psychological characteristics "significance" and "availability". So, the author values ranked not only by their importance, but also according to their implementation options in reality. In the field of importance includes leading life values, they include personal plans for life goals of future. In the field of availability includes everything that can be reached directly and are associated with specific goals which are located in the zone called "easy to reach zone". According to this method it is possible to calculate whether the value leads to internal conflict, internal vacuum is located in the neutral zone, as well as the value system of integrity/disintegrity indicator.

For both instruments was received permission from authors to use the instruments by an e-mail.

The author includes a demographic survey which includes questions about gender, age, monthly income, education, how long ago acquired a driver's license, how many kilometres they drive on average per month, how much warnings and violations they have received during past 3 years, the brand of personal car.

\subsection{Procedure}

The survey was published on the internet website (www.google.docs.com/) and participants were offered to fill out the questionnaire on the Internet, by placing ads in various social sites, like-minded groups and forums.

Sample was selected using the following criteria - acquired driver's license, gender, age.

Instructions for the participants were given clear and understandable; also an objective of the study was notified. They were informed that the data will be examined as a package and not individually, respondents were asked to provide real and not socially desirable answers. The survey took place during the period from 8 February to 21 April, 2016.

\subsection{Data processing methods}

Data was verified, entered in Microsoft Office Excel 2008, then imported to the program SPSS Statistics 21.0/22.0, where was carried out all the survey results processing. In the program SPSS 22.0 Statistics were calculated the results of descriptive statistics, Cronbach's alpha scores. To answer to the research question first was calculated the Pearson correlation coefficient, then, based on the results, was calculated hierarchical regression analysis (step method).

\section{Results}

To answer the research question: which of the individual value system characteristics (internal vacuum, internal conflict, the neutral zone, value system integrity/disintegrity indicator) predict driving behaviour (distracted driving, aggressive behaviour towards other traffic participants, risky driving, safe and courteous driving) controlling by gender and age, based on Pearson correlation coefficient hierarchical regression analysis was calculated. 
Table 1. Hierarchical regression analysis for independent variable value system integrity/disintegrity index and dependent variable distracted driving, controlled by gender and age.

\begin{tabular}{lcc}
\hline & \multicolumn{3}{c}{ Distracted driving } \\
\hline & $\overline{\mathrm{a}}$ & $\Delta R^{2}$ \\
1. Step & & 0.14 \\
Gender & -0.12 & \\
Age & -0.39 & 0.18 \\
\hline 2. Step & & \\
Gender & -0.17 & \\
Age & -0.35 & \\
Value system & $0.21^{*}$ & \\
integrity/disintegrit & & \\
y indicator & & 0.32 \\
Sum $\Delta R^{2}$ & & \\
\hline${ }^{*} p<0.05,{ }^{* *} p<0.01$. & &
\end{tabular}

To predict distracted driving, in the first step of regression analysis was included the gender and age. This model explains $14 \%$ of the variation, but it is not statistically significant. Based on Pearson correlation coefficient, in the second step in addition to gender and age was included value system of integrity/disintegrity indicator, which additionally explained $18 \%$ of the model and is statistically significant (Table 1 ).

Table 2. Hierarchical regression analysis for independent variable internal vacuum and dependent variable risky driving, controlled by gender and age.

\begin{tabular}{lcc}
\hline & \multicolumn{2}{c}{ Risky driving } \\
\hline & $\overline{\mathrm{a}}$ & $\Delta R^{2}$ \\
1. Step & & 0.09 \\
Gender & -0.18 & \\
Age & $-0.31^{* *}$ & 0.17 \\
\hline 2. Step & & \\
Gender & $-0.22^{*}$ & \\
Age & $-0.26^{* *}$ & \\
Internal vacuum & $-0.28^{* *}$ & 0.26 \\
Sum $\Delta R^{2}$ & &
\end{tabular}

To predict risky driving, in the first step of regression analysis included gender and age, this model explains $9 \%$ of its variations and age was found as statistically significant negative predictor for risky driving. Based on Pearson correlation coefficient, in the second step, in addition to gender and age was included an internal vacuum, in addition to explaining the $17 \%$ of this model and it was found as negative statistically significant predictor for risky driving (Table 2).

To predict safe and courteous driving, in the first step of regression analysis included gender and age, this model explains $12 \%$ of variation and age statistically significantly predict safe and courteous driving. Based on Pearson correlation coefficient, in the second step, in addition to gender and age was included in the neutral zone, in addition to explaining the $13 \%$ of this model, but it was not statistically significant (Table 3 ). 
Table 3. Hierarchical regression analysis for independent variable neutral zone and dependent variable safe and courteous driving, controlled by gender and age).

\begin{tabular}{lcc}
\hline & \multicolumn{2}{c}{ Safe and courteous driving } \\
\hline & $\overline{\mathrm{a}}$ & $\Delta R^{2}$ \\
1. Step & & 0.12 \\
Gender & -0.17 & \\
Age & $0.24^{*}$ & 0.13 \\
\hline 2. Step & & \\
Gender & -0.15 & \\
Age & $0.22^{*}$ & \\
Neutral zone & 0.15 & 0.25 \\
Sum $\Delta R^{2}$ & & \\
\hline${ }^{*} p<0.05,{ }^{* *} p<0.01$. & &
\end{tabular}

Table 4. Hierarchical regression analysis for independent variable neutral zone and dependent variable summary indicator of dangerous driving, controlled by gender and age.

\begin{tabular}{lcc}
\hline & \multicolumn{2}{c}{ Summary indicator of dangerous driving } \\
\hline & $\overline{\mathrm{a}}$ & $\Delta R^{2}$ \\
1. Step & & 0.17 \\
Gender & $-0.20^{*}$ & \\
Age & -0.42 & 0.22 \\
\hline 2. Step & & \\
Gender & $-0.25^{* *}$ & \\
Age & -0.38 & \\
Value system & $0.25^{* *}$ & \\
integrity/disintegrity & & 0.39 \\
indicator & & \\
Sum $\Delta R^{2}$ & &
\end{tabular}

To predict summary indicator of dangerous driving in the first step of regression analysis included gender and age, this model explains $17 \%$ of variation and gender is a statistically significant negative predictor. Based on Pearson correlation coefficient, in the second step, in addition to gender and age was included value system integrity/disintegrity indicator, which additionally explained $22 \%$ of the model and was negative statistically significant (Table 4).

\section{Discussion}

The aim of the research was to examine characteristics of individual value system prediction for driving behaviour.

The study has answered to the fundamental question: which of the individual value system characteristics (internal vacuum, internal conflict, the neutral zone, values system integrity/disintegrity indicator) predict driving behaviour (distracted driving, aggressive behaviour towards other traffic participants, risky driving, safe and courteous driving) controlling by gender and age.

The results show that distracted driving can be predicted by value system integrity/disintegrity indicator which may indicate the fact that if an individual's values do 
not match with the real possibility of reach the value and as a result, is affected his motivation sphere, which can be expressed with frustration, internal discomfort, internal conflicts, self-realization shortages and unclear own identity, it is more likely that he will not pay full attention to direct driving tasks while driving.

The results show that risky driving can be negatively predicted by age and internal vacuum, it may also indicate that young drivers often becomes involved in risky activities while driving in traffic, as well as the fact that individuals who values are more available than those he has actually necessary and important, it is more likely to drive a car in risky way. Some of these results are in line with previous studies. Summarising up the results of different studies, one can conclude that the best traffic accidents and violations predictors are age and sex [11-15].

The results indicated that a safe and courteous driving can be negatively predicted by age, probably can be attributed to young people's experience and immaturity, as well as the physiological processes that take the place in young person growing up process, many young people sought after self-affirmation, so are more inclined to choose the most risky driving, not safe and courteous driving, as evidenced by the preliminary results and studies. The research highlights that one of the factors that increase the likelihood to drive in risky and aggressive way is age [16].

The results show that the summary indicator of dangerous driving, so the trend in general to drive a dangerous manner, predicts sex, which is in line with the previous studies. Men cars often runs intoxicated and rarely wear seat belts, regardless of their age [17], men tend to show higher rates thoughts of revenge and physical aggression [18]. It also emphasized that one of the factors that increase the likelihood of aggressive driving is simply to be a man [16]. Also summary indicator of dangerous driving predicts value system integrity/disintegrity indicator, which means that if an individual's values do not match with the real possibility of reach value and as a result, is affected his motivation sphere, which can be expressed with frustration, internal discomfort, internal conflicts, selfrealization of the lack of and blurred own identity, it is more likely that he was driving a car driving a car in general will drive in aggressive, risky and dangerous way.

\section{Conclusions}

The aim of the study was achieved. Tasks of research were fulfilled and answers to research question received.

In Latvia until now have not been any studies, which reflect the individual value system, and driving behaviour relationships. Author believes that the choice of the theme is successful and useful for future research and this study although confirms the already existing and proven driving behaviour of forecasters, but also gives an idea about the factors that may incidentally affect driving behaviour.

Limitations of the research were related to the size of the sample, participant alignment, use of new instruments, as well as data collection method. Repeating this research would be desirable to increase the sample size and use of approbated instruments, as well as it would be interesting to find out how the factors of individual value system predict the objective number of accident and violations caused by driver. It would be necessary to obtain objective data on number of the road accidents and violations, as well as to collect data in person, also control the distribution of men and women groups.

The results can serve as the basis to create new driving behaviour interventions and also applicable to psychologist's professional work, when counselling individuals of this group, as well as can be used in the future development of the field, science and research. 


\section{References}

1. Perepjolkina V., Voita D. Latvijas Autovadītāju uzvedības aptauja. Tehniskā atskaite. Nepublicēts. 2011

2. Фанталова Е.Б. Диагностика и психотерапия внутреннего конфликта. Самара: БАХPAX-M. 2001

3. Jirgena S. Jauniešu pašizjūta un adiktīvas uzvedības izvēle. Promocijas darbs. Rīga: LU. 1999

4. World Health Organisation. Global status report on road safety 2013: supporting a decade of action. 2013

5. Cel̦u Satiksmes Drošības Direkcija. 2004-2014. gados notikušo Ceḷu satiksmes negadījumu, tajos bojā gājušo un ievainoto skaits. 2015

6. Lazdinš̌ K.J., Mārtinsone K. Autovadītāju agresijas un braukšanas uzvedības saistība ar personīgās automašīnas jaudu un virsbūves tipu. Nepublicēts bakalaura darbs. 2014

7. Dewar R.E., \& Olson P.L. Human factors in traffic safety. Tuscon, AZ: Lawyers \& Judges Pub. 2002

8. Muzikante I., Reng̊ge V. Autovadītāju individuālo vērtību saistība ar riskantu braukšanu. $L U$ raksti 768. 39-50. 2008

9. Rokeach, M. The nature of human values. New York: Free Press. 1973

10. Muzikante I. Vērtības, attieksmes un autovadītāju uzvedība uz cel̦a. Promocijas darbs. 2011

11. Krahe B., \& Fenske I. Predicting aggressive driving behavior: the role of Macho personality, age, and power of car. Aggressive Behavior 28, 21-29. 2002

12. Özkan T., \& Lajunen T. Why are there sex differences in risky driving? The relationship between sex and gender-role on aggressive driving. traffic offences, and accident involvement among young Turkish drivers.; Aggressive Behavior 31, 547558. 2005

13. Rhodes, N., \& Pivik, K. Age and gender differences in risky driving: The role of positive affect and risk perception.; Accident Analysis and Prevention. 2010

14. Stradling, S.G., \& Parker, D. Extending the theory of planned behaviour: The role of personal norm, instrumental beliefs and affective beliefs in predicting driving violations. 1997

15. Underwood G., Chapman P., Wright S., \& Crundall D. Estimating accident liability. 1997

16. Tasca L. A review of literature on aggressive driving research. Aggressive Driving Issues Conference. 1-11. 2000

17. Lancaster R., Ward R. The contribution of individual factors to driving behaviour: Implications for managing work-related road safety.; Research Report. HSE Contract Research Report: HSE Books, 3-60. 2002

18. Deffenbacher J.L., Petrilli R.T., Lynch R.S., Oetting E.R., \& Swaim R.C. The Driver's Angry Thoughts Questionnaire: A measure of angry cognitions when driving. Cognitive Therapy and Research 27, 383-402. 2003 
